\section{Michał Chmielecki}

Społeczna Akademia Nauk

mchmielecki@spoleczna.pl

\section{Łukasz Sułkowski}

Społeczna Akademia Nauk

Isulkowski@spoleczna.pl

\title{
Organizational Culture in Mergers and Acquisitions
}

Abstract: Mergers are a very important aspect of corporate growth. But so many mergers fail to achieve their aim. A lot of mergers won't produce value for the acquiring firms. Evidence and surveys have shown that corporate culture is very important for the success of mergers and acquisitions. This evidence also points to the fact that cultural differences are a very important factor that could lead to failures in mergers. Currently there is not much empirical evidence or theory on the importance of cultural differences for the performance of mergers and acquisitions. Though, there is a growing rate of interest in this area.

Key words: organizational culture, mergers and acquisitions, cultural differences, mergers, aqusitions

\section{Introduction}

In the last couple of years, there has been a fairly large number of mergers and acquisitions (M\&A). A lot of organizations continue to look for growth 
strategies that will enable them to remain competitive in a fast changing business landscape through mergers and acquisitions (Chmielecki, 2010). Even though corporate culture is important, very little research has been done on this topic in Finance and Economics. Much more work has been done in Organizational Behavior and different models of corporate culture has been created, but very few has been applied in the context of a mergers and acquisition.

Literature began to pay more attention to corporate culture in the 1980s, when a lot of books talked about the link between corporate culture, behavior of firm and performance. (Example, Deal and Kennedy, 1982 and Peters and Waterman, 1982). So much attention has been paid to this topic since then. Cameron and Quinn (1999) were of the opinion that almost every successful company has a unique, recognizable corporate culture. Corporate culture is the personality of its organization, its shared values, beliefs and behaviors. Corporate culture describes the way we do things here and it represents the implicit and explicit rules of organizational conduct. Culture is generally created by the founder of a firm (Disney for example), and tt usually progresses in different ways that are designed to promote the achievement of the organizational goals e.g. G.E. Nowadays more and more publications are being devoted to positive aspects of culture in management (e.g. Przytula, Rozkwitalska, Chmielecki, Sułkowski, Basinska, 2015).

Cartwright and Cooper opined that mergers will fall under three categories depending on how much culture change and integration is required. The three types of mergers according to them are: collaborative mergers (the success of the merger depends on the ability to blend the two cultures and create a culture that borrows from the two cultures, thereby creating a win/win scenario), extension mergers (open marriages in which dissimilarities in culture between merger partners are received and viewed as insignificant) or redesign mergers (these are traditional marriages and are usually the most popular type of mergers. Here the acquirer is dominant and replaces the culture of the smaller or less successful one, thereby cre- 
ating a situation where one partner loses and the other wins). The major insights are the following; Mergers fail majorly because one partner does not agree to or recognize the other partner's perception of the terms of the marriage. In a collaborative merger, the culture changes that are observed to exact more control on the employees will be less welcome than those that are seen to give employees more freedom. An acquirer with a culture of "Role" will be more welcome to a target with a culture of "Power" more than a target with a culture of "task". In a redesign merger, the more the differences, the tougher the integration process will be and the more time the integration process will take.

Previous literature mainly in the field of Organizational Behavior was used by Cameron, DeGraff, Quinn, and Thakor (2006) to describe the "Competing Values Framework". This framework has four quadrants. Each of the quadrant represents a type of corporate culture.

Table 1. Types of corporate culture

\begin{tabular}{|l|l|}
\hline collaborate & control \\
\hline create & compete \\
& \\
\hline
\end{tabular}

\section{Sources: Cameron, DeGraff, Quinn, and Thakor (2006).}

A collaborate-oriented culture is focused on developing people, building skills, building cohesion through consensus and promoting satisfaction through involvement ("human empowerment, human development and human commitment"). A lot of attention is given to the decentralized making of decisions, teamwork and training and development. A control-oriented culture concentrates on perfecting efficiency by executing better processes (cheaper, better, surer). In this type of culture, greater focus is placed on productivity and cost enhancements, efficiency improvement measures, reduction of manufacturing cycle time and risk reduction. A create-oriented culture is focused on process, service and product innovation ("innovate, 
create and conceive the future"). A lot of focus is placed on creating inventive extensions to a product line, creation of new technology and breakthrough in new processes. A compete-oriented culture is focused on competitiveness to the utmost ("compete greatly, move very fast and strive to win"). This type of culture is focused on external competitiveness that is weighed by customer satisfaction, sales, market share, shareholder value etc.

The Competing Values framework produces valuable insight. All four quadrants are present in all organizations but only one or two aspects dominate. An organization may be strong in the Create quadrant (e.g. Ideo) while another may excel in the Control quadrant (e.g. Emerson Electric). The quadrants experience tensions and "competing values" between diagonally-opposite quadrants. For example, Compete usually clashes with Collaborate while Create clashes with Control. This occurs because opposing quadrants places great value on contrasting forms of value creation. These tensions exist in each organization and they can help to predict the type of merger that will succeed. If, an organization whose Culture is based on Compete merges with an organization whose culture is based on Create, the "rules of conduct" across the two organizations may vary so much that it could be difficult to bring them back together which will result in the attrition of employees in one organization with a reduction in performance post-merger. In summary, Organizational Behavior literature usually interprets culture in the terms of descriptive categorizations of the behavior of particular cultures, so that culture can be seen from the view of what people believe will create value and the way they believe. Then culture becomes a variable that inspires group and individual behavior, and this influence is above and beyond the effect of explicit contracts (Rozkwitalska, Chmielecki, Przytuła, 2014).

Economics literature began to touch corporate culture about 10 years after Organizational Behavior literature. Kreps (1990) said in a seminal paper that corporate culture behaves like a coordination mechanism in situations that have various equilibria and it is a way of dealing with unfore- 
seen circumstances. The model introduced by Kreps focuses on situations where cooperation among the various parties is necessary. Another way of introducing cooperation is through contracts. But there are so many scenarios where formal contracts are expensive due to costs of enforcement, monitoring and bargaining. It could also be infeasible because the actions or states may not be verifiable or it is difficult to enumerate in advance.

According to Cremer (1993), corporate culture is the knowledge shared by a large population of the members of an organization but not by the general populace. He is of the opinion that the more shared knowledge exists in an organization, the stronger the corporate culture. He believes that members of an organization are trustworthy, but are very limited in their ability to receive, process and transmit information.

According to Lazear (1995), corporate culture is preferences or shared beliefs that come up due to an evolutionary process. His model shares the assumption that individuals in a firm have genetic endowments or preferences and that when two individuals meet, each of them produce a descendant with preferences obtained from a mix of the two mates. Senior management can make sure that some preferences will likely survive if it can nourish a specific culture. In practice, internalization and selection are the two ways it can do such.

When a merger or an acquisition fails, the costs are harshly visible. Generally, morale drops/ Combined actions start to fail and major people (the ones you plan to keep) start to exit the organization. But what is actually going on? Why is the system failing suddenly?

A probable cause of the trouble is a clash of culture.

In a culture clash, the primary way of working of the company is so diverse and easily misapprehended that that people feel uneasy and disappointed which will cause defections and demoralizations (Chmielecki, 2012). Productivity drops drastically and no one knows how to stabilize it.

Acquirers have elaborate resources for managing the operational and financial aspects of a deal. They always monitor the result of the deal close- 
Iy and their executives are accountable for meeting up with targets according to schedule. Merging two different cultures, might seem soft, difficult to measure and impossible to manage directly. Because of this, very few organizations apply the same energy to managing and commandeering integration of cultures the same way that they will do to a normal top notch synergy. No one is held responsible. Senior leaders might find themselves in the disconcerting position of looking at the problem develop without being able to do anything about it.

A company's corporate culture is the shared beliefs, behaviors and values that will show how members of an organization do things. There are three major elements that define the culture of a company. They are:

1) The company's operating model. That is, the governance mechanisms, the accountabilities, structures and the ways of working that determines the blueprint for how work will get done.

2) The important decisions and abilities about how and where to compete which is defined by the strategy of the company.

3) The behavioral norms that are shown by everyone ranging from the executives to the lowest employees.

\section{What does this mean for the merging of two companies?}

If everyone acted mainly on the basis of logical calculations that is the behavioral model that is preferred by economists, mergers might be effective based on how good their economic foundation is. Participants in mergers are effective based on how good their economic underpinnings her. Though all participants in a merger are human and are driven by their individual personalities and their shared culture. Cultural influences have the capability to be broad and far reaching: 
Table 2.Elements affected by culture in mergers and aquisitions

\begin{tabular}{|c|c|}
\hline Elements affected by culture & Results \\
\hline $\begin{array}{l}\text { Decision-making style (E.g.: top-down } \\
\text { contrasted with consensus) }\end{array}$ & $\begin{array}{l}\text { Efficient integration requires fast deci- } \\
\text { sion-making. } \\
\text { Various decision-making styles can lead } \\
\text { to slow taking of decisions, failure to } \\
\text { implement decisions or failure to make } \\
\text { decisions. }\end{array}$ \\
\hline $\begin{array}{l}\text { Leadership style (E.g.: consultative or } \\
\text { dictatorial, diffuse or clear) }\end{array}$ & $\begin{array}{l}\text { Any shift in the style of leadership can } \\
\text { produce turnover among employees who } \\
\text { oppose the change. This is very true for } \\
\text { top talent, who are usually the most mo- } \\
\text { bile employees. } \\
\text { The loss of top notch talent can quickly } \\
\text { cripple value in an integration by draining } \\
\text { intellectual capital and market contacts. }\end{array}$ \\
\hline $\begin{array}{l}\text { The ability to change (this is the willing- } \\
\text { ness to risk new things, compared with } \\
\text { meeting current goals and with focus on } \\
\text { maintaining the current state) }\end{array}$ & $\begin{array}{l}\text { There will be a disinclination to imple- } \\
\text { ment new strategies. } \\
\text { Disinclination to work through the una- } \\
\text { voidable difficulties that occur as a result } \\
\text { of creating a new company. }\end{array}$ \\
\hline $\begin{array}{l}\text { How people work together (E.g.: based } \\
\text { on formal structure and the definition of } \\
\text { roles or based on relationships that are } \\
\text { informal) }\end{array}$ & $\begin{array}{l}\text { Merged companies will create interfaces } \\
\text { between functions that will come from each } \\
\text { of the companies, or new functions that will } \\
\text { blend people from the legacy companies. If } \\
\text { the legacy companies'cultural assumptions } \\
\text { are unstable, then handoffs and processes } \\
\text { may dissolve gradually with each compa- } \\
\text { ny's employees becoming frustrated by } \\
\text { the failure of their colleagues to identify or } \\
\text { understand how work should be done. }\end{array}$ \\
\hline $\begin{array}{l}\text { Beliefs on the issue of personal "success" } \\
\text { (E.g.: organizations that are focused on } \\
\text { team work or on individual "celebrities," } \\
\text { or where } \\
\text { people ascend through connections with } \\
\text { their seniors) }\end{array}$ & $\begin{array}{l}\text { Again, these differences could lead to } \\
\text { cracks in getting work done. If people } \\
\text { whose notion of "success" places great } \\
\text { emphasis on individual performance } \\
\text { merge with people who believe they have } \\
\text { to achieve goals as a team, the scenario } \\
\text { that results is often one of lack of support } \\
\text { for getting the job done and personal } \\
\text { dislike. }\end{array}$ \\
\hline
\end{tabular}

Source: own elaboration based on Taneja, M., \& Saxena, N. (2014) Mergers and Acquisitions with a reference to Ethical, Social and Human Resource. Journal of Business and Management (IOSR-JBM), Volume 16, Issue 3, pp. 69-72. 
Culture is a concept that is subject to change (Sułkowski, 2002). It is a set of influences that people cannot explain precisely or totally. Due diligence before a merger will fish out things that can be measured with a focus on finances. Assessment tools and cultural surveys can be used to measure culture, but these can take so much time to complete. The period of deal-making usually starts the luxury of an extensive effort to test soft variables. Even if any culture assessment is undergone during due diligence, it is very difficult to imagine that a merger or joint venture is aborted due to the fact that due diligence showed that the culture of the two companies were incompatible. In most cases, culture hardly stops a proposed merger, it is the duty of the people that are overseeing the deal to prevent culture from ruining their goals. The most commonly used method to managing issues pertaining to culture is to create a set of appetizing cultural attributes (an exemplary set is decisive, innovative, team-oriented, customer focused, respectful of others and entrepreneurial) and then to implore employees to take up these attributes in their behavior daily. Organizations are full of coffee mugs, posters, mouse pads, screen savers and other items that serve to remind their employees of these attributes. But this particular method is not supported by the "success" stories of many. The attributes are usually universal in nature and it will be a struggle for the employees to unite select ways driven by a culture that get things done in the organization and the broad principles that are easy to agree with.

One of the major characteristics of integration after a merger is the pressure of time. So many tasks have to be quickly completed. That kind of environment will not offer quality time for a detailed examination of culture or a culture change project over a wide range of time. The possibility of achieving goals in the organization is quite doubtful at this period. It is suggested that there should be a more concentrated approach. This approach should be based on pinpointing the major point of high risks in the creation of the merged company and working with all the employees to bring down the way culture will increase these risks. 
The major risks change in every merger and they need to be pinpointed case by case. Then a list of risks that occur the most can be selected as a point of beginning for more detailed analysis. These integration risks include: establishing the fact that the interfaces that affect value most (In the chain of supply) between the two companies work very effectively. Establishing a joint approach to making decisions that will achieve the right decision making and speed.

Establishing an internal brand that is valueable to the employees of this newly formed company should be formulated in a way that is appealing to all the employees of the two companies. This will differ according to whether the merger is a joint venture on one hand or a merger between equals or the sheer integration of one company with another. In a situation where things are not equal, the culture and brand of the acquirer is expected to dominate. This culture should be presented to the employees of the acquired company in a way that they will value it. This is very true for cases where the acquiring company wants to retain the acquired employees in a hostile takeover. When two equals are merging, the best approach is to look towards the creation of a new culture. Understanding of the compensation program in each company and taking steps to incorporate them in a way that the employees will see them as beneficial to their interests. An intensive program with objectives that are clearly stated should be used to address the integration of cultures.

\section{Summary}

So many times, culture is treated as a soft topic that shouldn't be focused on. When this happens, the senior executives ignore the issue in these cases. This should be avoided by linking cultural program to significant results in business.

It is quite enticing for organizations to drive strategic growth through mergers and acquisitions. Anyone who has undergone or studied the pro- 
cess of mergers \& acquisitions will tell you that the journey to meeting up with financial expectations is not smooth and that there are quite a large number of things that could go wrong. Organizational culture is one of the most overlooked factors that could lead to the failure of a M\&A. 


\section{References}

Cameron, K.S., DeGraff, J., Quinn, R.E., Thakor, A.V. (2006) Competing values leadership: Creating value in organizations. Edward Elgar.

Cameron, K.S., Quinn, R.E. (1999) Diagnosing and changing organizational culture. Prentice Hall Series in Organizational Development.

Chmielecki, M. (2010) Komunikacja międzykulturowa w procesie zarządzania negocjacjami. rozprawa doktorska, Społeczna Wyższa Szkoła Przedsiębiorczości i Zarządzania w Łodzi.

Chmielecki, M. (2012) Cultural barriers of knowledge management-a case of Poland. Journal of Intercultural Management, 4(2), 100-110.

Cremer, J. (1993) Corporate culture and shared knowledge. Industrial and Corporate Change, 2, 351-386.

Deal, T.E., Kennedy, A.A. (1982) Corporate cultures: The rites and rituals of corporate life. Addison-Wesley.

Kreps, D.M. (1990) Corporate culture and economic theory, Perspectives on positive political economy. Ed. J.E. Alt, K.A. Shepsle. Cambridge University Press, 90-143.

Kreps, D. (1990) A course in microeconomics. Princeton University Press, Princeton, NJ.

Lazear, E.P. (1995) Corporate culture and diffusion of values, Trends in business organization: Do participation and cooperation increase competitiveness? Ed.H.Siebert. J.C.B. Mohr/Paul Siebeck, Tubingen, 89-133. 
Peters, T., Waterman R.H. Jr. (1982) In search of excellence: Lessons from America's best-run companies. New York: Harper \& Row.

Przytuła, S., Rozkwitalska, M., Chmielecki, M., Sułkowski, Ł., \& Basinska, B.A. (2015). Cross-Cultural Interactions between Expatriates and Local Managers in the Light of Positive Organizational Behaviour. Social Sciences, 86(4), 14-24.

Rozkwitalska, M., Chmielecki, M., \& Przytuła, S. (2014) The positives of cross-cultural interactions in MNCs. Actual Problems of Economy, July (7).

Sułkowski, Ł. (2002) Kulturowa zmienność organizacji. Polskie Wydaw. Ekonomiczne.

Taneja, M., \& Saxena, N. (2014) Mergers and Acquisitions with a reference to Ethical, Social and Human Resource. Journal of Business and Management (IOSR-JBM), Volume 16, Issue 3. 